Journal of Teacher Education for Sustainability,

vol. 14, no. 2, pp. 111-129, 2012

\title{
ACTION RESEARCH FOR CREATING KNOWLEDGE IN AN E-LEARNING ENVIRONMENT
}

\author{
Jānis Kapenieks \\ Riga Technical University, Latvia \\ Ilga Salite \\ Daugavpils University, Latvia
}

\begin{abstract}
The paper describes an action research during the implementation of an e-learning course on commercial studies in a bachelor's programme. The action research study aims to: 1) determine the effectiveness of action research in a technologically-based learning environment and 2) establish how group work in e-learning environment affects students' interest in, and need for, communication and discourse. Qualitative and statistical methods of data analysis were used in this mixed-methods study. The present paper analyses the experience of students working in three action phases to design their personal frames of reference for evaluation of the content and metacontent of business fundamentals. The study identified several possibilities for improving elearning environment with techniques that make this form of learning more sustainable.
\end{abstract}

Key words: educational action research, e-learning, learning environment, group work, lived experience, living theory

\section{Introduction}

Action research is one of the contemporary approaches to educational research and creation of new knowledge (Salīte, Mičule, Kravale, Iliško, \& Stakle, 2007; Herrington \& Weaven, 2008; Keiny, 2008; Salīte, 2008; Dick, 2009; Salīte, Gedžūne, \& Gedžūne, 2009; Whitehead, 2009). Action research is suitable for identifying problems of social development and seeking their solution. This approach is particularly appropriate at a time when nations and communities face dramatic changes caused by the introduction of new technologies (Stringer, 2008). To satisfy the newly arisen needs, approaches are sought for more extensive use of e-learning in education.

The present paper aims to identify new opportunities for the use of Information and communication technology (ICT) in fostering students' creation of personal knowledge and skills while mastering a course on the fundamentals of business in a technology-based environment. The study was conducted with a broader educational research aim - to identify 
the opportunities of using action research to foster acquisition of e-learning study courses and to evaluate the influence of e-learning techniques on the extension of cooperation and discourse in an e-learning environment. The above-mentioned educational aim is viewed in this study in a contemporary context that emphasises e-learning methods and the use of technologies requisite for their implementation. It is one of the most prominent features in knowledge society. Technological possibilities and the new societal needs on the way towards knowledge society enhance the rapid development of e-learning.

\section{Theoretical framework}

Knowledge society requires new approaches to education. The ever-increasing usage of various technical means to create e-learning environment for knowledge acquisition warrants a scrutiny of the pedagogical implications of these technological advances. A critical examination of their educational outcomes is of crucial importance. The rapid development of ICT over the last decades has created great instruments for the formation of knowledge society. Yet, many e-learning projects that are based on the experience of industrial society have also created 'bubbles' (e.g. the internet bubble) that tend to burst, but are able to give new experience. Up to now in the global practice, the implementation of ICT solutions has been largely unsuccessful because the content of development projects is generally determined by technological opportunities whereas research into the users' behaviour and flow of knowledge is neglected (Kapenieks, 2009).

The chief goal for cooperation between pedagogical researchers and ICT scientists is to identify the aims to be reached and adapt the developed ICT instruments to the educational needs of knowledge society. One of such opportunities is a combination of individual and group autonomous learning in e-learning environment where learners' meaningful knowledge is created in cooperation and discourse is an indispensable component of the knowledge-making process. In this respect, it is important to evaluate the opportunities and limitations of technologies and programmes (Loveless, 2007) which take the form of e-learning as well as to seek solutions for a more successful usage thereof or find ways to compensate for the said limitations by improving the design of e-learning or perhaps identifying other effective pedagogical solutions.

Although e-learning is relatively new in education, its application has already resulted in the elaboration of several approaches and guidelines for creation and further development of e-learning design (Clark \& Mayer, 2007). These suggestions are grounded in the science of instruction and aim to help consumers and designers of multimedia learning reach the bipartite aim of e-learning: inform and perform (Clark \& Mayer, 2007). This double goal permeates the instructional methods and suggestions that are meant to help learners effectively process and assimilate new knowledge and skills.

E-learning is dominated by two learning approaches - instructional methods and cooperative methods in e-learning environment. An evaluation of the contribution of digital technologies to learning allows for viewing technological opportunities in terms of clusters 
of purposeful activities: creation of knowledge, distributed cognition, community and communication, involvement (Fisher, 2006). Instructional knowledge acquisition is characterised by delivery of knowledge (Clark \& Mayer, 2007). Cooperative methods feature acquisition and creation of knowledge in cooperation. They can be subdivided into cooperative and collaborative methods. In cooperative e-learning, several learners each create a part of a joint project and the discrete parts are ultimately assembled in an end-product. In collaborative learning, learners work together to complement each other's ideas that result in a shared project (Salmon, 2004).

Clark and Mayer (2007) believe that the main task in this case is designing an e-learning environment which would support the learners' cognitive abilities. They also define six basic principles for instructional e-learning 1 ) maximum use of pictures; 2) close proximity of words and pictures; 3 ) maximum use of the spoken text; 4) avoiding duplication of information in the written and graphic form; 5) avoiding superfluous and attractive information and 6) maximum use of personalisation by creating the material in the form of a personalised conversation. These principles are grounded in research into the cognitive processes of knowledge acquisition and should be considered when designing an e-learning environment for knowledge creation. In this case, however, it is more important to create a design that would motivate creative activity, generation of new ideas and their exchange with peers.

Acquisition of business regularities is often taken as a medium to research the expediency of using e-learning to motivate learners for knowledge acquisition (Mayer, 2001). Additionally, business-oriented study courses are frequently used to research tutor's (consultant's) activities. Salmon (2004) has studied the role of an e-learning consultant and the principles of e-learning model design to increase student motivation, enhance socialisation, information exchange and knowledge creation. She proposes a five-stage teaching and learning model (Salmon, 2002). The first stage should ensure access to the learning environment, the second permit students to create online identities. Cooperation in the third stage is possible because each participant supports the aims of others. In the fourth stage, with the development of discourse, cooperation becomes more intensive and purposeful. In the fifth stage, participants find new gains which help them realise personal aims that reflect the learning process. The level of interactivity differs across stages, but it is crucial in information exchange and knowledge construction.

In all cases, complex systems of educational solutions are considered effective owing to the crucial role of interaction between technologies and humans within them (Tilbury, 2007). Purg and Zakrajšek (2009) argue that systems that unite the human and technological factors can be implemented by creating complex models where the possibilities of information and communication technologies are used for both knowledge delivery and evaluation while sustainability is ensured by cooperation networks (Purg \& Zakrajšek, 2009).

This paper will refer to several specific issues selected from a broader study which explored the opportunities to improve the quality of e-learning. The selected range of issues pertaining to e-learning will be discussed in the context of complementary usage of particular processes 
from both personalised autonomous and cooperative learning. Bridging these two types of learning, especially the dynamic interplay between them both in the educational process, is an issue of significance in the context of the quality of learning outcomes. Our previous studies were focused on evaluation of these two types of learning in the context of the quality of e-learning environment which was created in educational action research.

Contemporary pedagogical and sustainability perspective underscores the importance of viewing the relationship between humans and technology in light of learners' lived experiences and extension of the latter with the outcomes of complementarily applied autonomous personalised and cooperative learning forms. This interplay of old and new experiences and the learners' seeking a meaningful purpose for their learning creates conditions for learners to use their lived experiences to create personally meaningful living theories that expand and deepen their assumptions about the essence of sustainable development and, on a more general scale, sustainability, arrived at via individual studies and group work.

The present paper presents an account of our experience and some findings from the application of such a perspective on pedagogy and sustainable education to implement educational action research embedded in the process of study course acquisition.

\section{Action research as a learning environment for the creation of 'living theory'}

The use of action research analysed in the present paper is grounded in the philosophy created by Dewey at the end of the 19th century (Dewey, 1916). It is likewise the basis for the e-learning method which has been applied in various projects; the method is rooted in the holistic approach that permits to activate students' creative potential. This philosophy is a prerequisite for the tendencies that dominate contemporary education - personalisation and student-centredness of knowledge acquisition. On the grounds of Dewey's philosophy, Lewin (1946) created the fundamentals of action research theory. Kemmis and McTaggart (2000) highlight the importance of participation in action research and suggest answers to significant questions: comparison of action research and 'scientific' research, the importance of participation and its influence on social processes. Dick (2009) provides a broader analysis of the evolution of action research theory until 2007.

Recently, many studies have demonstrated that action research approach is effective for motivating students and enhancing their participation (Herrington \& Weaven, 2008) as well as for fostering self-education (Keiny, 2008). Experience indicates that people perceive information much easier if they are solving real-life situations (Kapenieks \& Jirgensons, 2008). Attributes which are integral aspects of autonomous learning are the following: the ability to motivate oneself; the ability to work autonomously; the general management of one's own work to time limits; a flexible and adaptive mind able to face new situations, the ability to think creatively, self-critically and independently.

Several authors suggest incorporating grounded theory in action research. A significant step in theory development was the introduction of the concept of grounded theory by Glaser and Strauss (1967). When people act, they usually predict the result of their action, namely - 
it is their theory. Such theories are usually informal and relate action to its results. Grounded theory is a systemic and qualitative research method where theory is generated through data instead of hypothesis, which might seemingly contradict more 'scientific' methods. Practical theories differ from scientific ones by at least three parameters. Firstly, they are viewed as instruments or tools. Secondly, practical theories are openly heuristic because they use concepts and instruments that permit various interpretations of one and the same situation. Thirdly, practical theories envisage actions that lead to the improvement of the current situation (Barge \& Fairhurst, 2008). Introduction of the notion of grounded theory was the turning point in social sciences since it added new significance to qualitative research (Charmaz, 2000). Whitehead (2009) developed the method of grounded theory into the living theory approach to educational practice. It is grounded in human ability to create personal and unique explanations to the educating influences encountered in the learning process.

These theories are sensitive towards the situation of their creators. Yet, they can go beyond it and reveal heretofore unpredicted causal dimensions in the relationship between the participants and their environment. It helps co-create theoretical knowledge about the causal conditions of the social world (Friedman \& Rogers, 2009). Creation of a meaningful theory in action research is the basis for creation of a shared local understanding among community members, which frequently enables them to take a critical stance to the dominant discourses (Genat, 2009). Acquisition of situational knowledge is facilitated by reflection and conceptualisation of action in cooperative groups. Joint researches and their evaluation develop selfassurance and decrease unwavering faith in authoritarian knowledge (Koutselini, 2008).

Explanation principles are the embodiment of the flow of energy and its manifestation in action. Their opposites are propositional theories where action explanations and individuals' learning are detached from the conceptual abstractions of the interrelations among propositions. Living theories are generated by action researchers in the practice of knowledge creation. Living theories integrate insights from both kinds of theories without lessening their abstract and conceptual understanding (Whitehead, 2009).

\section{Method}

The present paper describes an experience gained during the implementation of a mandatory study course on the fundamentals of business in a bachelor study programme at the Faculty of Electronics and Telecommunication of Riga Technical University.

Research participants:

1. Student participants. 199 first-year students (32 females and 167 males) participated in the study. They all have adequate computer knowledge and skills. Some of the participants consider knowledge about business fundamentals especially important in view of their intended going into business.

2. Researcher/e-learning consultant. In the process of action research the researcher/ consultant cooperated with course tutor and students. Close partnership developed with the tutor with regards to choosing course content and meta-content, 
analysing its process and outcomes. Students and the consultant met regularly during classes every two weeks. When students performed the tasks of each action research phase, the consultant supervised their activity in the e-learning environment. Should the occasion arise, the consultant became directly involved - commented on the students' performance, motivated them via e-mail or messages in the e-learning environment. Upon completion of each cycle of knowledge acquisition, the consultant evaluated the students' performance.

For the purpose of this action research study, knowledge creation was divided into acquisition cycles. Figure 1 depicts a knowledge acquisition spiral that illustrates the strategy of acquisition. It is grounded in the systemic constructionist approach which posits that research should address three important discursive practices: 1) construction of meaning; 2) positioning and 3) performance. Each acquisition cycle begins with the identification of the problem to be solved. In each cycle, on the grounds of autonomous learning and communication within the group (network), a lived experience is actualises and some generalisations located as a resource for the building of living theory which is further developed in each consecutive cycle.

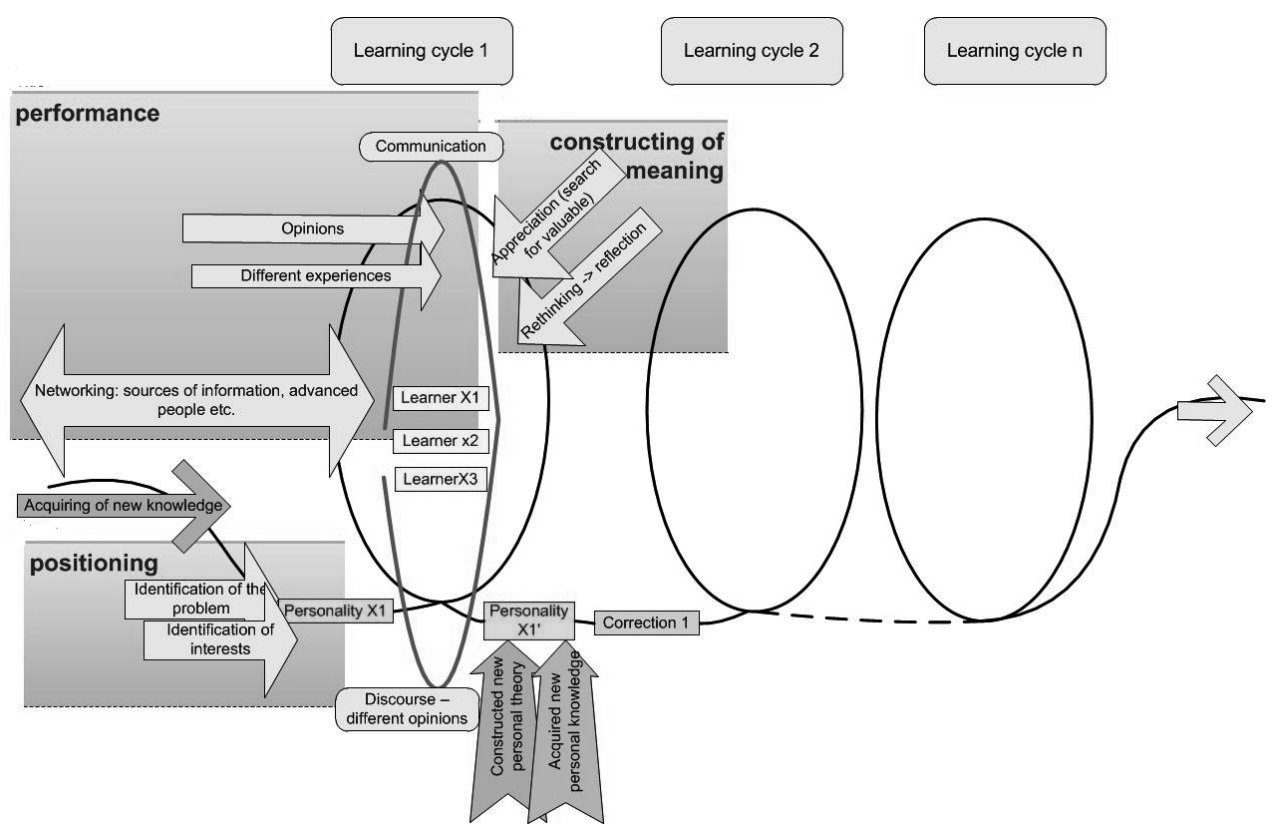

Figure 1. Continuity of project-based learning via action research in the course "Business Planning for the Open Market" (Kapenieks, 2010)

Creation of living theory is based on contemplation and evaluation, which are grounded in personal beliefs, experience and interests. Contemplation and searching for the valuable result in reflection. Predictably, the process of theory generation changes learners' interests and beliefs, which are recorded at the beginning and end of each cycle. Communication with co- 
participants introduces various experiences in the process of generating theory, which results in discourse. At the end of each acquisition cycle, the living theory is analysed and some corrections are introduced if necessary. At this point, the tutor and the e-learning consultant both play the crucial role - that of observing and investigating individual or autonomous learning and group learning' as well as using these types of learning to become involved in problem identification and solution in all three action research phases.

The problem to be solved during educational action research is planning a successful financial flow for students' business ideas - enterprises. The learning process is organised by using a project-based approach - planning the income/expense, balance and tax policy of one's enterprise.

Students work in groups of four to six and participate in three action research phases (cycles). During the introduction class of the first cycle, they become familiar with the chief regularities and concepts. Students find success stories in business and learn more about them. Each proposes their business idea (an enterprise) and designs a business plan. Prior to action research, students attend a class where they are introduced to the course and its aim, and where output data are defined. The problems and issues to be addressed in the first cycle are also defined. At the beginning of the acquisition cycle, students' interests are determined as well as their motivation for mastering the study course, related experience and beliefs.

The first phase begins with each student answering the questions asked in a Google Docs environment about the income/expense planning for their enterprise. Then group mates add to each other's ideas, and each student summarises the discursive opinions in a living theory. Each student's ideas are complemented by two peers. E-learning consultant evaluates each student's input and adds some correction if necessary. He also monitors the process and motivates students during the classes and via e-mail. The second and third phases of action research are characterised by a similar process. Each student creates their living theory about the balance and tax policy of their enterprise, which would be the most effective in business. As a result, each student develops a personal frame of reference for evaluation of the content and meta-content of the study course on the fundamentals of business, thus creating personal knowledge and approaches, and expanding own interests and beliefs.

Each member of the learning community is a source of experience for others. The blue lines in Figure 2 indicate how beliefs are constructed and developed in each acquisition cycle. 


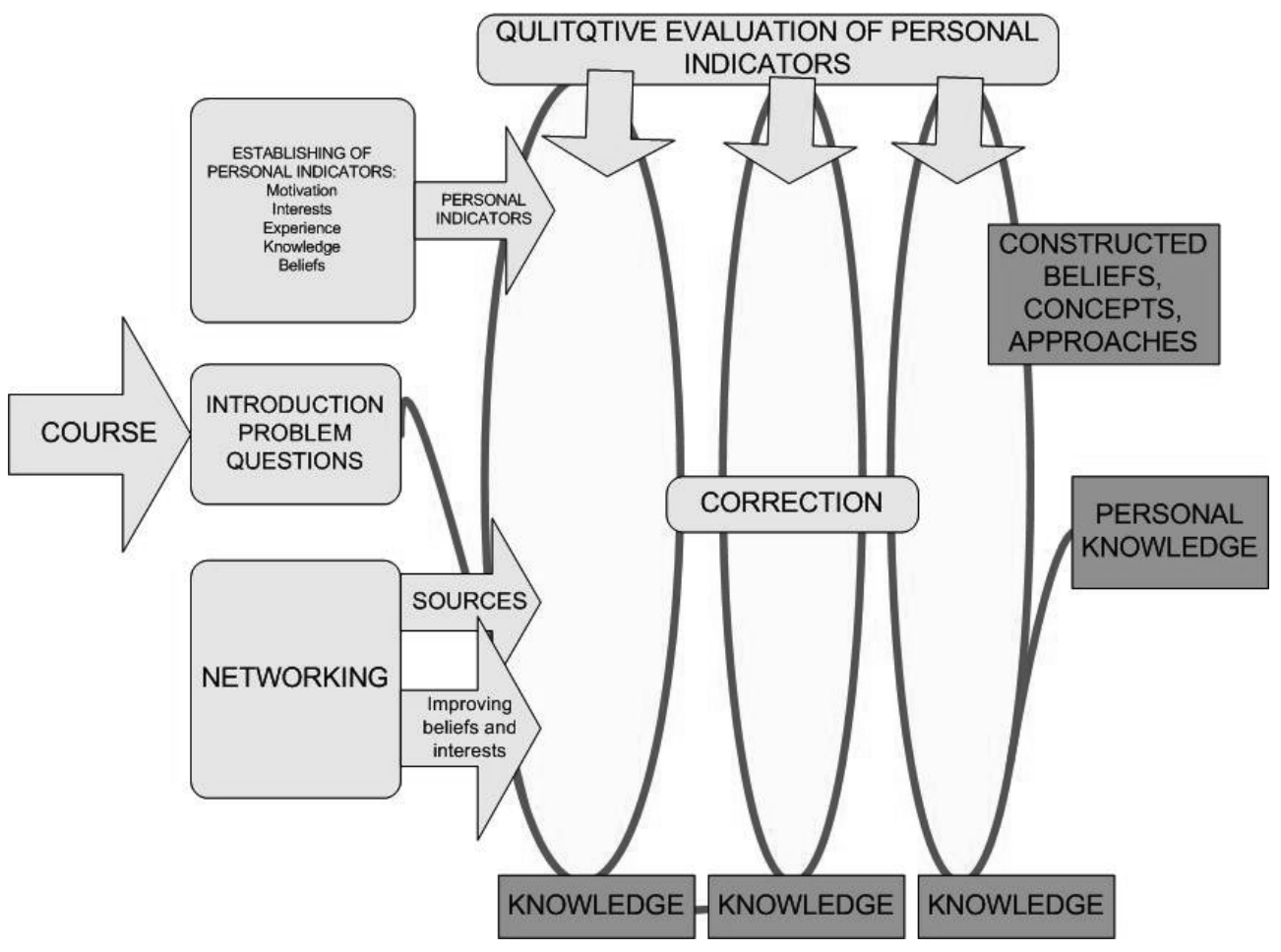

Figure 2. Development of personal knowledge during course acquisition in action research

By gaining new knowledge, students enter each consecutive cycle with complemented beliefs. While creating the living theories, students acquire personal knowledge which includes new beliefs, conceptual knowledge and approaches. The system of content knowledge is grounded in inductive and deductive analyses.

\section{Design of the e-learning environment}

The opportunities provided by the e-learning portal 'ORTUS' of Riga Technical University were used to coordinate action research. The portal is designed by using open code software Moodle. In this environment, students receive directions about the tasks to be completed, are able to download learning materials and task templates as well as upload the tasks after completing them. Action research was conducted in Google Docs environment. Here students answer questions and their answers are summarised in a MS Excel table. The e-learning consultant groups the students and ensures each student's access to their group table in the editing or viewing mode. In the group table, the students add to each other's opinions, summarise them in a living theory and can view the tutor's corrections and evaluation. This environment affords a possibility for several students to work in one and the same table as well as provides a convenient way of communication via e-mail between group members and the tutor. The latter opportunity is used for motivating students. 
The first questions in Google Docs environment help determine students' interests and beliefs in which the first acquisition cycle is subsequently grounded.

During the first acquisition cycle, students need to answer some questions in Google Docs environment. These questions encourage students to seek regularities in the functioning of their enterprise. Some of the questions to be answered in the first cycle are the following:

- What kinds of income do you expect to receive in your enterprise?

- What criteria will you apply for choosing your target clientele and who will they be?

- Please characterise the geographic, demographic, professional and social segmentation of the market.

- Please characterise the aims for setting the prices.

After completing the questionnaire, all group members can view the answers and comment them in a MS Excel table. In this table, the students summarise their own and their peers' opinions in a living theory by participating in a communicatively created discourse. The tutor also uses the tables to add his comments, corrections and evaluation. In the second and third acquisition cycles, the e-learning environment is designed in a similar way.

\section{Results}

177 students out of 199 completed two cycles of creating living theory whereas 148 went through all three cycles. In each cycle, students were divided into groups of four to six in the order of filling in the questionnaire form. Each group worked in one document; each student created their own living theory in cooperation with two group mates. Participation in the educational action research gave students a possibility to upgrade their final assessment.

100 students participated in a voluntary survey about the course upon its completion. Generally, the target group was responsive and asked questions both during the classes and via e-mail. During the cycles, e-learning consultant sent reminder e-mails about the work to be done, which invariably caused an increase of activity. The increase of activity was also observed shortly before the end of the course.

The effectiveness of the creation of living theory was evaluated in two ways: 1) by analysing the results of course acquisition and 2) by conducting a qualitative study - an in-depth interview with the course tutor.

The study yielded an extensive amount of data, which will be presented selectively in this paper in order to 1) give a general illustration of the study and 2) underscore the core finding of qualitative analysis - identification of prototype ideas which can be used to create living theory.

Pierson's correlation confirmed the intuitively perceived relation between the final evaluation of creating the living theory at the end of each knowledge cycle and the total evaluation of the acquisition of the respective portion of the course. Pierson's correlation coefficients are, respectively: 
- $\quad 0.167$ (0.05 is significant) in the first cycle (income/expense)

- 0.217 (0.01 is significant) in the second cycle (balance)

- 0.179 (0.05 is significant) in the third cycle (taxes)

In the survey, the students answered the question if creation of living theory helped to prepare the project - financial flow table. $80 \%$ (80) of students agreed. 23 of them used their own ideas in the living theory whereas $18 \%$ (18) reported that they had also taken into consideration their peers' ideas. The rest admitted that the creation of living theory was mainly helpful in mastering the new concepts.

The course tutor evaluated the students' activity, motivation and acquisition quality by comparing it to the results of the previous years. He appreciated the students' interest and an increase in activity during course acquisition this year as compared to the previous years. The quality of knowledge acquisition among students was considerably higher than before.

The majority of students agreed that the applied method of knowledge creation was interesting. The students assessed their personal gains from using the method. Their evaluation is depicted in Figure 3.

What did you gain from creating a living theory?

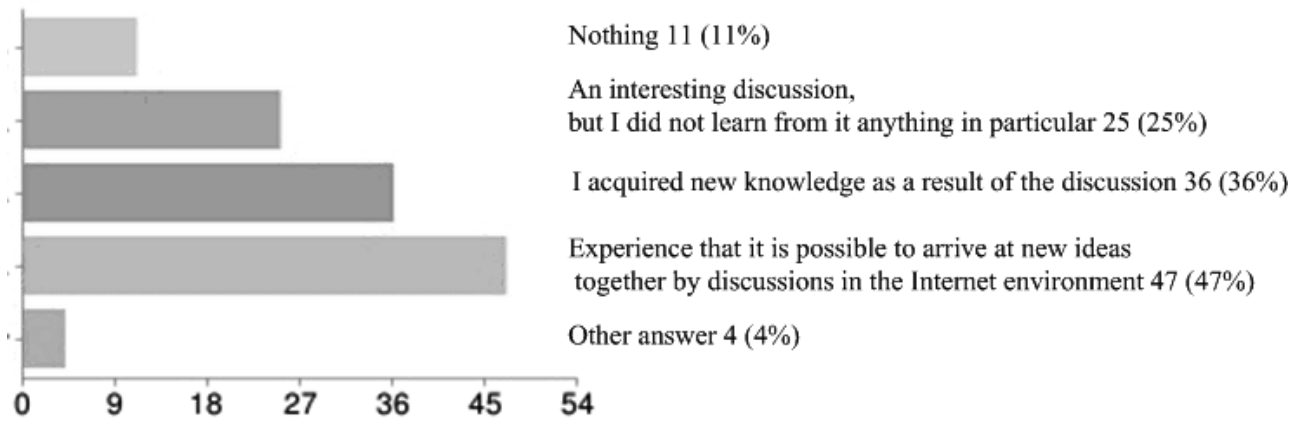

Figure 3. Students' evaluation of their gains from using the living theory method (100 respondents)

The method might first have appeared complicated since students had to repeatedly and independently complete tasks in an internet environment and cooperate in the process. That is why it was important to establish if students found it difficult to understand the tasks to be performed. 23\% (23) of the students who participated in the survey understood everything at once, 55\% (55) reported that it was difficult to start with but they quickly understood the tasks to be done. $13 \%$ (13) of students only understood what needed to be done at the very end.

Key to group work in e-learning environment is each student's access to computer and the internet as well as appropriate computer skills. 64\% (64) of students had constant access to the above whereas $11 \%$ (11) found they did not manage to complete the tasks successfully because of access problems to ICT. The Google Docs environment which had been used 
for group work was considered ideal for the task by $24 \%$ (24) of students, but the majority awarded it between 4 to 5 points (41\%).

Since group mates participated in creation of living theory with their opinions, it was expected that this participation would have had some contribution to the acquired knowledge. Students' evaluation of this issue is depicted in Figure 4.

\section{Assess the contribution of your group mates to your knowledge.}

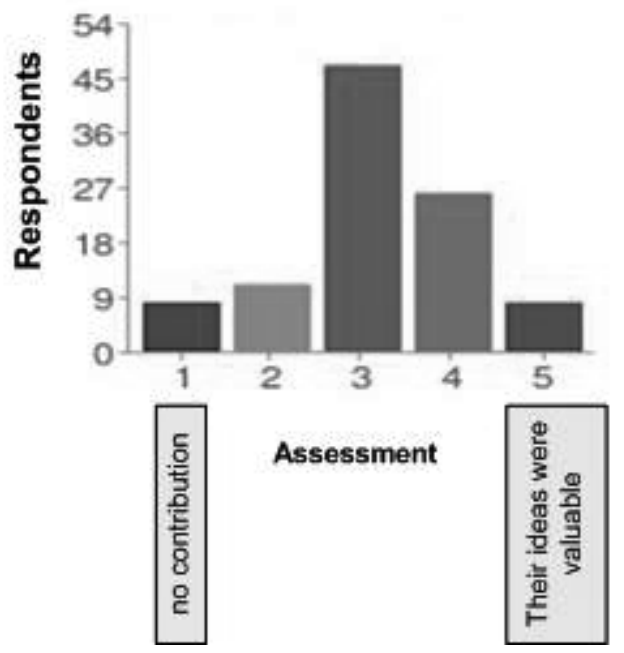

Figure 4. Students' evaluation of their contribution to their peers' theories

Group work also affected the students' activity and motivation. 62\% (62) of the students confirm it by stating that they liked their peers' contribution to their ideas. 36\% (36) enjoyed evaluating their peers' performance whereas $24 \%$ (24) of students liked summarising their own and their group mates' ideas in a living theory.

As a result of communication, during the creation of living theory, e-learning environment acquired some features of a social network. Since students from various academic groups worked together, they were often unacquainted. $28 \%$ (28) of students met their group mates in person and discussed the tasks to be performed.

Group work also caused some problems. 23\% (23) of students struggled to understand what their peers had meant in their theories whereas 34\% (34) found it difficult to complement their colleagues' ideas. Psychological factors are also important. $30 \%$ (30) admit that they were afraid to harm their peers with their ideas and were concerned it would affect their group mates' final mark (although it had been stated before that this would not happen).

Analysis of the creation of living theory across the seven groups of the first cycle reveals that no explicit leaders appeared within the groups who would assume the leadership of the group as it usually happens during class work. Nevertheless, mutual influence is highly pro- 
nounced in e-learning environment: if someone from the group does the task on a high level, others will presumably try to follow the lead and be like him/her. The situation is similar with discursive opinions - if a group member expresses many discursive opinions, an extended discourse develops within the group. Thus in three out of seven groups at least $80 \%$ (4) of students performed more than $90 \%$ (11) of the procedures (the latter include filling in the form, commenting a group mate's opinion on one issue, summarising the opinions in a living theory; the maximum number of procedures in the first cycle is 12). The quality of acquisition in such groups was considerably higher than in others.

Similar mutual influence was observed in some of the groups with poorer performance, yet it was not as pronounced as in those described above. In group work, students depend on each other's performance. Thus, a student we shall call Liene writes, "It would be nice if the tempo of my work were not so much dependant on the diligence of other people; I mean, I had to wait until others evaluated my work".

Since students had to perform several procedures in each knowledge acquisition cycle (up to 12 in the first cycle) and repeatedly access the shared group document (at least four times during each cycle), students' activity plays the crucial role in knowledge acquisition. One of the motivating factors is communication with the tutor. It comprises a 30 -minute introduction during a class lecture before each cycle, motivational letters in cases when activity plummets, the tutor's commentaries in the shared document about the mid-cycle performance and corrections to the living theory at the end of each cycle, as well as evaluation of the students' performance. Figure 5 illustrates how motivational letters affected the students' activity in the first acquisition cycle.

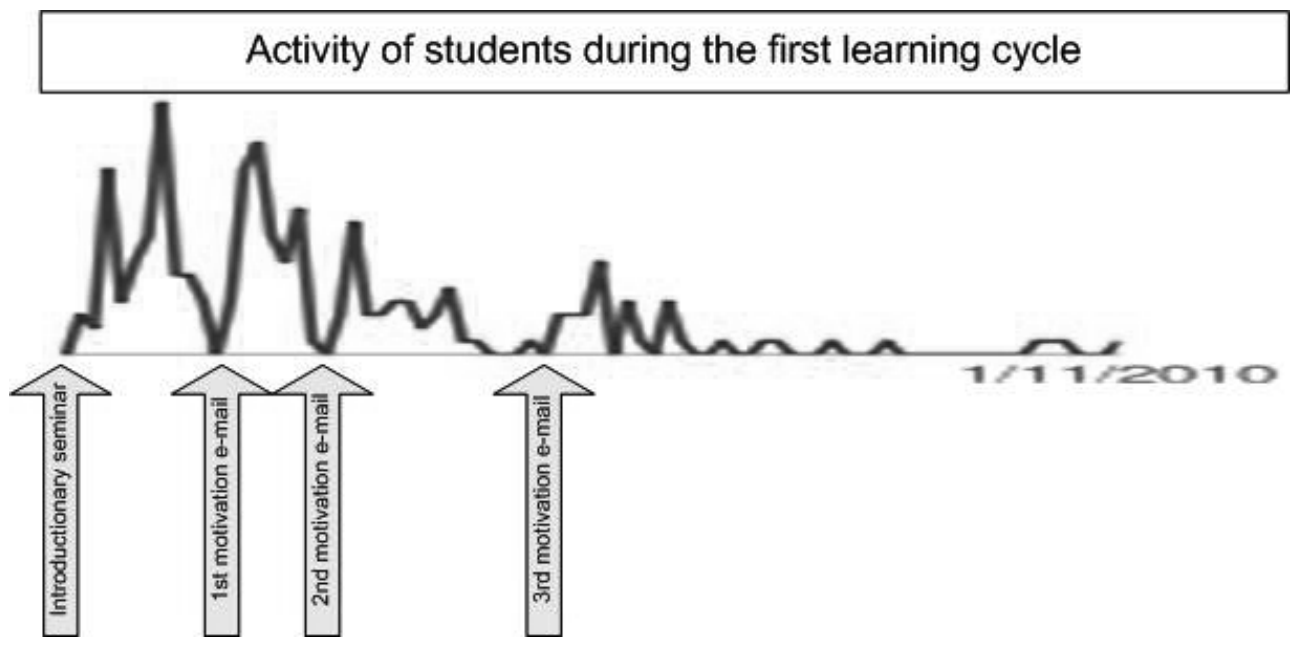

Figure 5. Influence of motivational letters on students' activity in the first acquisition cycle

The students also used the chance to ask questions via e-mail, which were answered as soon as possible. 
In the final questionnaire, the students evaluated their communication with the tutor, and $25 \%$ (25) estimated it as very good (the maximum score on a five-point scale). $52 \%$ (52) of students awarded it four points, 19\% (19) - three points whereas $4 \%$ (4) only gave two points. None of the students regarded communication as insufficient. Figure 6 depicts the students' opinions on what they gained from communication with the tutor.

\section{Importance of the communication with the consultant (100 respondents)}

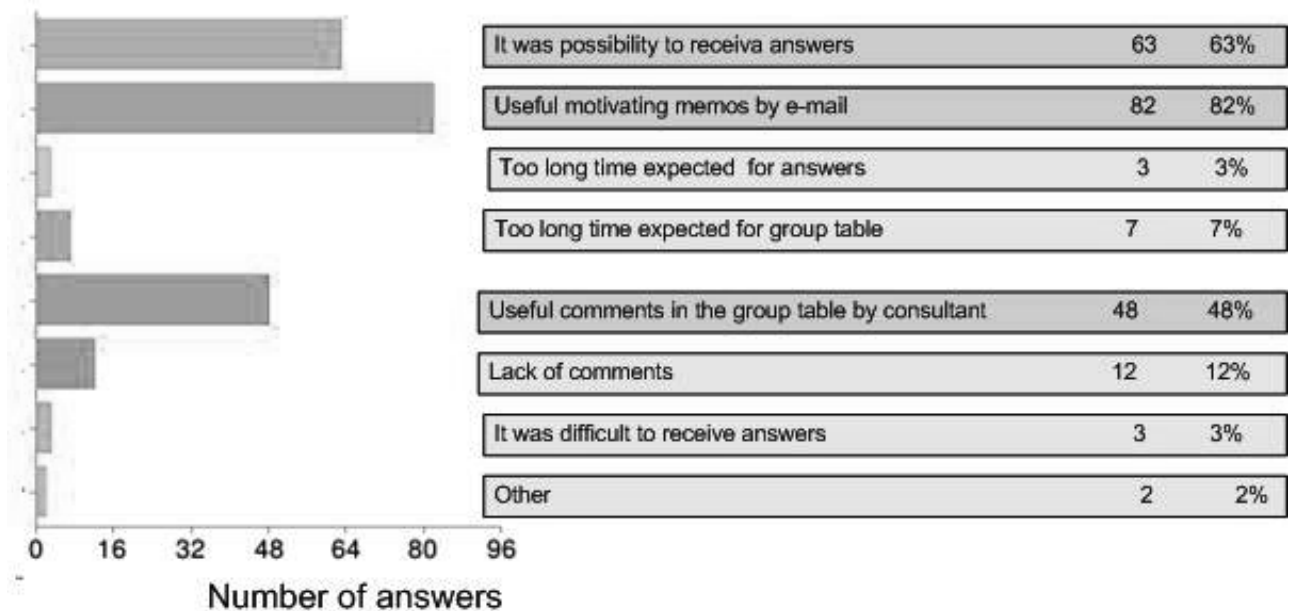

Figure 6 . Students' opinion about the importance of communication with their tutor

Following the termination of the course, the students were given an opportunity to comment on their impressions from the method of educational action research as well as propose suggestions for improving it. The majority enjoyed creating knowledge with this innovative method. 93\% (93) of the students believe the method should be used in other study courses. Anna writes:

I find this method very progressive; it should be popularised and widely used because it permits to find out other people's opinions, which is very important since, by learning more about people's views, we can objectively judge our own ideas and quickly make a summary. I generally did well; my group mates' opinions helped a lot.

A turning point in the qualitative analysis of data was the identified need to introduce the concept of prototype. The student-generated comments suggested the presence of some prototypes with distinct inherent features in the students' lived experiences. In Google Docs texts where the students complemented their peers' ideas on conditions for successful running of their businesses, it was perceived that the students' living theories were constructed around prototypes with specific innate features. Some students' writings were analysed in the first knowledge acquisition cycle where they evaluated each others' business ideas in terms of expected income and expense, target group of buyers, market segmentation, price planning 
policy and expected financial flow.

Here are some examples. For instance, student Eve adds to student Armand's idea about the formation of expense. She believes that Armand will need to make several purchases which will significantly increase the price of the end product. Armand includes this idea in his living theory as a feature of the prototype of target buyer "buyer's solvency" which, in its turn, leads to an identification of a target buyer - prototype "middle class" (Table 1).

The business idea of another student, Christine, is selling multimedia navigation blocks for cars. Her living theory includes prototypes whose features were derived from complementary discourse generated by her fellow students Peter and Mark. Mark believes that older people will not be among target customers due to their being more conservative and likely to select car accessories that are easier to use. Christine transforms this discourse into a prototype feature "attitude towards new technologies" and, consequently, in her living theory she does not include senior customers who are not supportive of new technologies in her target group of buyers.

Student Eugene complements group discourse with his suggestion: it is important that a new business idea is not only profitable, but also does some good to the world. Accordingly, student Christine identifies reputation as a prototype feature of a business's sustainability and includes the prototype "securing the company reputation" into her living theory.

Not all students' contributions to discourse eventually transform into prototypes. Thus, student Inga's business idea about selling a high-quality detailed interactive map does not result in a prototype about extra expense incurred from purchasing or designing the map - a piece of discourse contributed by Paul.

Table 1 contains some other examples of prototype formation which occurred on the grounds of discourse generated from lived experience.

Table 1. Transformation of the discourse generated from students' lived experiences into prototype features and corresponding prototypes in educational action research

\begin{tabular}{lll}
\hline Discourse & Prototype feature & $\begin{array}{l}\text { Prototype in the liv- } \\
\text { ing theory }\end{array}$ \\
\hline Great expense from different purchases & Buyer's solvency & $\begin{array}{l}\text { Target buyer - middle } \\
\text { class }\end{array}$ \\
\hline $\begin{array}{l}\text { Older people will not be among target customers } \\
\text { due to their being more conservative and likely to } \\
\text { select car accessories that are easier to use }\end{array}$ & $\begin{array}{l}\text { Attitude towards new } \\
\text { technologies }\end{array}$ & $\begin{array}{l}\text { Target group does } \\
\text { not include senior } \\
\text { customers not } \\
\text { supportive of new } \\
\text { technologies }\end{array}$ \\
\hline $\begin{array}{l}\text { The suggested price must be higher than the loss- } \\
\text { threshold }\end{array}$ & Mean price & $\begin{array}{l}\text { Finding mean price } \\
\text { to be increased or } \\
\text { reduced accordingly }\end{array}$ \\
\hline $\begin{array}{l}\text { The business idea will be implemented and will } \\
\text { benefit the world; one cannot always focus business } \\
\text { exclusively on profit }\end{array}$ & Reputation & $\begin{array}{l}\text { Securing company } \\
\text { reputation }\end{array}$ \\
\hline $\begin{array}{l}\text { You will need to attract customers and surpass all } \\
\text { leading business in your sphere. Good luck to you }\end{array}$ & Advertising & $\begin{array}{l}\text { Focus on advertising } \\
\text { the product }\end{array}$ \\
\hline
\end{tabular}


An analysis of students' discussion and living theories suggests that in many cases they transform discourse into prototype features and prototypes. These prototypes, in their turn, become the grounds for living theories about the specific problems related to their business ideas.

\section{Discussion and implications for further studies}

The present study explores a way of organising discussion in a technologically grounded learning environment and thus sustaining conditions for reflexive creation of personally meaningful living theory. The making of living theory is a creative process compatible with endeavours to develop a knowledge society by integrating ICT in the learning process, personalising knowledge, fostering creativity and facilitating research skills.

The study confirms the importance of learning environment in the educational process and ascertains the correspondence of the e-learning environment used in educational action research to Dewey's (1916) perception of a sound learning environment. It enables tracing students' cooperation and reflection without assuming excessive control of their work. Elearning consultant's presence emerges as a motivating factor in the study. The consultant follows reflection as it unfolds in the e-learning environment and affects the students through this environment. This relationship derives specific implications for the personalisation of environment. Environment stimulates meaningful growth which, in the present context, entails an improved understanding of business processes in different situations. In this study, the environment was shaped according to Dewey's criteria. Growth was the result of reflection as students became engaged in discussion and interactively pursued their personal educational aims.

Such developments correspond to education for sustainable development. Demand for a high skilled workforce will increase (it has been estimated that from 2006 to 2015 the demand for high skilled specialists will rise by $2.4 \%$ (12.5 million jobs from 2008) while the demand for medium skilled specialists will increase by $1.0 \%$ whereas a decrease in demand by $1.9 \%$ is expected with regards to low skilled workforce) (Cedefop, 2008). The qualification level of high skilled specialists corresponds to ISCED (International Standard Classification of Education) level 5 and ISCED level 6. These levels require profound theoretical knowledge and research skills based on innovative and creative thinking and theoretical and practical know-how.

Educational action research sets high demands for e-learning environment and demands its improvement. The Google Docs infrastructure used in the present study ensures the functionality that is necessary for educational action research. At the same time, it has a number of shortcomings in interface design, such as insufficient personalisation and an uncomfortable layout in a Google Docs spreadsheet. Upgrading user-friendliness and personalisation are two key directions for future studies of interface design.

Educational action research highlighted several novel considerations which can be developed in educational philosophy and pedagogy and become the grounds for development of 
e-learning theory. One of such issues which can contribute to advances in both theory and practice is using the potential of action research as an e-learning environment for autonomous learning in terms of both individual work and group work. In a knowledge society, such learning environment can serve to develop valuable habits of mind.

The study uncovered the compatibility of living theory and prototype theory. Careful scrutiny of the opportunities afforded by both these theories can result in a set of suggestions to be qualitatively analysed by action researchers. For a researcher can find the transformation process from lived experience to prototypes to living theory challenging as it is not easy to separate these phenomena. A blurring of boundaries and an overlapping of features in this transformation is a complex, adaptive and evolutionary process on the one hand and a development of a virtuous habit of mind on the other hand, greatly affected by the quality of e-learning environment.

Action research permitted to identify new research directions for a broader use of the proposed innovative method:

- integration of action research approach in various study courses, including science, social sciences and the humanities;

- behavioural studies of students in e-learning environment with an aim to render this kind of work more effective;

- dynamics of students' interest while acquiring personal knowledge through creation of living theory in a group in e-learning environment;

- possibilities for diagnosing and developing cognitive and metacognitive skills by integrating action research approach with e-learning methods;

- improving the design of e-learning environment so that learners feel comfortable and teachers can fully contribute their intellectual resources to communication about the studied topic instead of organising the groups and addressing the technological issues.

\section{Conclusion}

So far, no attempts have been described to use action research by integrating the living theory method for creation of personal knowledge in groups within e-learning study courses. Project-based knowledge creation and acquisition can be organised in a group by using the methodology of action research in e-learning environment. Since the method is oriented towards cooperation, such software opportunities should be used that permit to access other opinions and complement them with one's personal experience, thus creating discourse and comparing experiences. Google Docs environment is appropriate for group work and formulation of living theory. This way, it is possible to create personally significant knowledge.

Action research demonstrates that this method considerably improves students' motivation, interest and activity in acquisition of the study course. The quality of the acquired knowledge increases noticeably as many students master the skill of expressing and substantiating discursive opinions as well as the courage to do so. Nevertheless, the students' activity 
tends to decrease with each consecutive cycle.

The study highlights the crucial role of communication in motivating students and sustaining their activity throughout the entire period of knowledge creation. Within this method, communication in group exhibits some features of a social network. While working in groups, students affect the quality of each other's work, yet no leaders appear. Tutor's interest is significant for enhancing students' motivation. Corrections to students' ideas should only be added at the end of each acquisition cycle.

This method can be used for acquisition of various study courses. Yet, it requires additional research and perfection of technological solutions.

\section{Acknowledgement:}

This work has been developed within the framework of the ICTeESD project that has been funded from the European Commission (ERASMUS Multilateral Programme Virtual Campus Project No. 510212-LLP-1-2010-1-GR-ERASMUS-EVC (2010-3494). The content of the paper reflects the views of the authors, and the Commission cannot be held responsible for any use which may be made of the information contained therein.

\section{References:}

Barge, J. K., \& Fairhurst, G. (2008). Living leadership: A systemic constructionist approach. Leadership, 4(3), 227-251.

Cedefop. (2008). Future skill needs in Europe. Medium-term forecast. Luxembourg: Office for Official Publications of the European Communities.

Charmaz, K. (2000). Grounded theory: Objectivist and constructivist methods. In N. Denzin \& Y. Lincoln (Eds.), Handbook of qualitative research (pp. 567-607). London: SAGE publications.

Clark, R., \& Mayer, R. (2007). E-learning and the science of instruction: Proven guidelines for consumers and designers of multimedia learning. San Francisco: Jossey-Bass/Pfeiffer.

Dewey, J. (1916). Democracy and education. New York: The Macmillan Company.

Dick, B. (2009). Theory in action research. Action Research, 7(5), 5-12.

Fisher, T., Higgins, C., \& Loveless, A. (2006). Teachers learning with digital technologies: A review of research and projects. Retrieved May 13, 2012, from http://archive.futurelab.org. $\mathrm{uk} /$ resources/publications-reports-articles/literature-reviews/

Friedman, V., \& Rogers, T. (2009). There is nothing so theoretical as good action research. Action Research, 7(1), 31-47.

Genat, B. (2009). Building emergent situated knowledge in participatory action research. Action Research, 7(1), 101-115.

Glaser, B., \& Strauss, A. (1967). The discovery of grounded theory: Strategies for qualitative 
research. Chicago: Aldine.

Grišāne, O. (2008). Designing environment for research and learning in secondary school. Journal of Teacher Education for Sustainability, 10, 17-31.

Hansen, D. (2002). Dewey's conception of an environment for teaching and learning. Curriculum Inquiry, 32(3), 267-280.

Herrington, C., \& Weaven, S. (2008). Action research and reflection on student approaches to learning in large first year university classes. The Australian Educational Researcher, 35(3), $111-136$.

Kapenieks, A. (2009). Zināšanu sabiedrības tehnologijas un jaunā mūžizglīiība [Technologies of knowledge society and new lifelong learning]. Latvijas vēsture [History of Latvia], $1(73), 6-14$

Kapenieks, J. (2010). Empowering users by applying the action research approach in e-studies. In S. Hambach, A. Martens, D. Tavangarian \& B. Urban (Eds.), eLearning Baltics 2010 (pp. 173-182). Rostock: Fraunhofer Verlag.

Kapenieks, J., \& Jirgensons, M. (2008). Context sensitive m-learning objects to correspond to content-level requirements. In E. Auer (Ed.), Interactive computer aided learning ICL 2008 (pp. 1-15). Villach: Kassel University Press.

Keiny, S. (2008). 'Conceptual change' as both revolutionary and evolutionary process. Teachers and Teaching: Theory and practice, 14(1), 61-72.

Kemmis, S., \& McTaggart, R. (2000). Participatory action research. In N. Denzin \& Y. Lincoln (Eds.), Handbook of Qualitative Research (pp. 567-607). London: SAGE publications.

Koutselini, M. (2008). Participatory teacher development at schools: Processes and issues. Action Research, 6(1), 29-48.

Lewin, K. (1946). Action research and minority problems. Journal of Social Issues, 2(4), 34-46.

Loveless, A. M. (2007). Creativity, technology and learning - a review of recent literature. Retrieved May 10, 2012, from http://archive.futurelab.org.uk/resources/documents/lit_ reviews/Creativity_Review_update.pdf

Mayer, R. E. (2001). Multimedia learning. Cambridge: Cambridge University Press.

Purg, P., \& Zakrajšek, S. (2009). New technologies for sustainable teaching and learning: A case study from Slovenia on diminishing student workload and increasing motivation through ICT. Journal of Teacher Education for Sustainability, 11(2), 31-40.

Salīte, I., Mičule, I., Kravale, M., Iliško, D., \& Stakle, A. (2007). Toward the sustainability in teacher education: Promise of action research. In A. Pipere (Ed.), Education \& Sustainable Development: First Steps Toward Changes” (Vol. 2, pp. 263-292). Daugavpils: Daugavpils University Academic Press "Saule".

Salite, I. (2008). Educational action research for sustainability: Constructing a vision for the future in teacher education. Journal of Teacher Education for Sustainability, 10, 5-16. 
Salīte, I., Gedžūne, G., \& Gedžūne, I. (2009). Educational action research for sustainability: Seeking wisdom of insight in teacher education. Journal of Teacher Education for Sustainability, 11(2), 14-30.

Salmon, G. (2002). E-tivities. London: Kogan Page.

Salmon, G. (2004). E-moderating: The key to teaching and learning online. London: Routledge Falmer.

Stringer, E., Guhathakurta, M., Masaigana, M., \& Waddell, S. (2008). Guest editors' commentary: Action research and development. Action Research, 6(2), 123-127.

Tilbury, D. (2007). Learning based change for sustainability: Perspectives and pathways. In A. Wals (Ed.), Social learning towards a sustainable world (pp. 117-132). Wageningen: Wageningen Academic Publishers.

Whitehead, J. (2009). Generating living theory and understanding in action research studies. Action Research, 7(1), 85-99.

Wicks, P., \& Reason, P. (2009). Initiating action research: Challenges and paradoxes of opening communicative space. Action Research, 7(3), 243-262.

\section{Correspondece:}

Jānis Kapenieks, PhD candidate, Distance Education Study Centre, Riga Technical University, Azenes Street 12, Riga LV-1048, Latvia. Email: janis.kapenieks@gmail.com 